

\title{
Evaluation of in vitro antioxidant and antidiabetic potential of extracts from Phaseolus vulgaris $L$. seeds (Black turtle beans)
}

\begin{abstract}
Balkisu O. Abdulrahman ${ }^{1,2}$ Muntari Bala ${ }^{3}$ and Bello Oluwasesan M. ${ }^{4}$
${ }^{1}$ National Center for Natural Products Research, School of Pharmacy, University of Mississippi, University, MS 38677, USA ${ }^{2}$ Department of Biochemistry and Molecular Biology, Faculty of Life Sciences, Federal University Dutsin-Ma, Katsina, Nigeria ${ }^{3}$ Department of Biochemistry, Faculty of Basic Medical sciences, Bayero University Kano, Nigeria ${ }^{4}$ Department of Applied Chemistry, Faculty of Physical Sciences, Federal University Dutsin-Ma, Katsina, Nigeria.
\end{abstract}

Corresponding author: Balkisu O. Abdulrahman. Department of Biochemistry and Molecular Biology, Faculty of Life Sciences, Federal University Dutsin-Ma, Katsina, Nigeria

Submission Date: June 30 $0^{\text {th }}$ 2021; Acceptance Date: September 28 ${ }^{\text {th }}$, 2021; Publication Date: September $30^{\text {th }}, 2021$

Please cite this as: Abdulrahman B.O., Bala M., Oluwasesan B.M. Evaluation of in vitro antioxidant and antidiabetic potential of extracts from Phaseolus vulgaris L. seeds (Black turtle beans). Functional Food Science 2021. 1(9): 23-38. DOI: $\underline{\text { https://www.doi.org/10.31989/ffs.v1i9.821 }}$

\section{ABSTRACT}

Introduction: Phaseolus vulgaris $L$ also known as common beans or black turtle beans are known worldwide as the most important legume for direct human consumption. Many parts of the plant are known to have important pharmacological potential against many diseases including diabetes. Despite the importance of this legume, P. vulgaris remains an underutilized and under-researched legume in Nigeria. Its therapeutic potential is being overlooked and undermined due to insufficient data on its bioactivity. These bioactive compounds present in some plant derived foods are found as fraction, crude extract, and isolated bioactive compounds that have been screened for antioxidative and antidiabetic potential. Several plant-derived foods and isolated bioactive compounds with potential antidiabetic properties are very limited.

Objective: To investigate and estimate the antioxidative and antidiabetic effect of the different solvent extracts of $\mathrm{P}$. vulgaris seed in vitro.

Methods: Samples were subjected to antioxidant assays using 1,1-diphenyl-2-picryl-hydrazyl (DPPH) radical scavenging activity, ferric reducing power and 2,2-azino-bis (3-ethylbenzothiazoline)-6-sulfonic acid (ABTS) Antidiabetic potential in vitro was estimated by evaluating various solvent extracts on $\alpha$-amylase and $\alpha$-glucosidase for any inhibitory effects at doses ranging from $(100-500 \mu \mathrm{g} / \mathrm{ml})$. Characterization of possible bioactive constituent in the different solvent extract was done using FTIR spectroscopy.

Results: Aqueous extract showed a higher number of total polyphenol (11.3 $\pm 0.01 \mathrm{mg} / \mathrm{gGAE})$ and anthocyanin content of $76.34 \pm 1.12 \mathrm{mg} / \mathrm{g}$ when compared with the other solvent extract. This was followed closely by the 
ethanol extract with a value of $7.3 \pm 0.01 \mathrm{Mg}$ and $74.53 \pm 0.24 \mathrm{Mg} / \mathrm{g}$. Ascorbic acid had a significantly higher $(\mathrm{P}<0.05)$ activity in the antioxidant assays used. However, among the solvent extracts tested, ethanol extract displayed highest $(P<0.05)$ for ferric reducing power activity, $(80.78 \pm 0.6 \mathrm{mg} / \mathrm{ml})$, ethyl acetate, aqueous and ethanol extracts had similar DPPH activities $(12.92 \pm 2.30 \mathrm{mg} / \mathrm{ml}, 12.59 \pm 2.33 \mathrm{mg} / \mathrm{ml}$ and $12.54 \pm 2.30 \mathrm{mg} / \mathrm{ml})$ respectively. Dichloromethane, hexane, ethanol and ethyl acetate had similar ABTS activities. $(5.69 \pm 2.86 \mathrm{mg} / \mathrm{ml}$; $6.92 \pm 0.14 \mathrm{mg} / \mathrm{ml} ; 10.10 \pm 1.11 \mathrm{mg} / \mathrm{ml} ; 10.76 \pm 2.98 \mathrm{mg} / \mathrm{ml}$ ) respectively. All solvent extracts displayed similar inhibitory activities against $\alpha$ amylase. However, ethyl acetate, aqueous and ethanol extracts showed significantly $(P<0.05)$ higher values for $\alpha$-glucosidase $(3.07 \pm 0.61 \mathrm{mg} / \mathrm{ml} ; 2.82 \pm 0.14 \mathrm{mg} / \mathrm{ml} ; 2.60 \pm 0.61 \mathrm{mg} / \mathrm{ml})$. The Fourier Transform infra-red spectrophotometer (FTIR) of the extracts disclosed that the presence of polyphenol and flavonoids were due to the $\mathrm{OH}$ stretching and the terpenes were due to the $\mathrm{C}-\mathrm{H}$ group.

Conclusion: In conclusion, different solvent extracts from the seed of Phaseolus vulgaris have demonstrated low antioxidative but very promising anti-diabetic activities in vitro. The ethanol extract however displayed higher activity than other solvent extracts, FT-IR results of ethanol extracts revealed the presence of flavonoids, anthocyanins and phenolics. This study may further suggest that seeds of Phaseolus vulgaris signify a functional food as well as a nutraceutical in terms of managing of Type 2 diabetes.

Keyword: Phaseolus vulgaris, $\alpha$ amylase, $\alpha$ glucosidase, antioxidative



CFFC 2021. This is an Open Access article distributed under the terms of the Creative Commons Attribution 4.0 License (http://creativecommons.org/licenses/by/4.0) 


\section{INTRODUCTION}

The long history of researching medicinal properties of plants and the identification of the chemical components that are responsible for their activity have justified healing wisdoms and the enduring healing potential of many plant medicines [1]. Plants have long provided mankind with herbal remedies for many diseases, and they continue to play a major role in the field of primary health care as new therapeutic remedies in developing countries [2]. Phytochemicals have become great interest in the last few years as they have been increasingly found in plants food as bioactive compounds. The interest peaked because they have been linked to the reduced progression or prevention of chronic diseases such as cancer, heart disease, and degenerative diseases. Promotion of healthy diets, nutrition, and lifestyles to reduce the global burden of these diseases is continually being advocated for, and a possible way out is the copious consumption of functional foods, nutraceuticals, and value-added food products, due to their ready availability and diseases preventing characteristics [3].

Diabetes mellitus is a chronic metabolic disorder that is of great public health concern. It can occur two ways, either as a result of pancreatic defect in secreting insulin or in the failure of one's receptor cells to effectively use secreted insulin, or both.

Globally, diabetes mellitus is growing exponentially with 463 million adults presently living with the disease. This defect causes high increase in blood sugar, which can eventually lead to significant damage to kidney, eyes, heart, blood vessels and nerves. [4, 5]. Nigeria is ranked highest in Africa. More than 95\% of cases of diabetes in Nigeria are Type 2 diabetes [6]. Development of diabetes complication is mainly caused by hyperglycemia. Hyperglycemia damage occurs in cells in which glucose uptake is independent of insulin, which is similar to what happens in beta-cells, it has been reported that the cause of the complications resides inside the cells [7]. Factors that contribute to the development of diabetes complication include hypertension and dyslipidemia. The development and progression of damage is directly linked to hyperglycemia; hence the lowering of glucose levels is the most important strategy for preventing complications and treating diabetes [8]. An antioxidant is any substance that can slow down or prevent the oxidation of a particular substrate [9]. There is a growing interest for the use of natural antioxidants and antidiabetic due to the less perceived side effects and its low cost. Currently, modern synthetic antidiabetic drugs are used to control diabetes; however, there are rarely any of these drugs without disadvantage. Studies have shown that certain bioactive compounds in foods have various disease fighting properties [10]. Some plant derived foods that are in the form of crude extract fractions and have isolated bioactive have been screened to find any antioxidative and antidiabetic potential [11-12]. A number of plantderived foods and isolated bioactive compounds with potential antidiabetic properties are very limited.

Phaseolus vulgaris $\mathrm{L}$ also known as common beans or black turtle beans is the most important legume worldwide for direct human consumption [13]. Various parts of the plant have been shown to have important pharmacological potential against many diseases [14]. Black bean's seed has been used by some families in Western Cameroon in the management of sickle cell disease. Consumption of the cooked black bean seed weekly significantly reduced the frequency of the crises in sickle cell patients [15]. The mature bean pods have been reported to have weak antidiuretic effect [16]. It has also been documented to have been use in tradition medicine for various ailments. Previous studies have reported antioxidative, anticancer, antidiabetic of $P$. vulgaris [17-19]. Most of the studies carried out on 
the legume focused on its seed coat. Moreover, P. vulgaris is an underutilized and under-researched legume in Nigeria [20]. Its therapeutic potential is being overlooked and undermined due to insufficient data on its bioactivity, and the bioactive compounds present therein. This research work was designed to investigate and evaluate the potential antioxidative and antidiabetic effect of the different solvent extract of P. vulgaris seed grown in Nigeria. Furthermore, characterization of the possible bioactive compounds was carried out using FTIR.

\section{MATERIALS AND METHODS}

Chemicals and reagents: Pancreatic alpha amylase, human salivary amylase 3, 5-dinitrosalicylic acid (DNSA), starch soluble, Streptozotocin, yeast $\alpha$ glucosidase $p$-nitrophenyl- $\alpha$-D-glucopyranoside (pNPG), p-nitrophenol, acarbose, 1,1-diphenyl-2picrylhydrazyl radical (DPPH) maltose, absolute ethanol, ethyl acetate, trichloroacetic acid, hydrogen peroxide, ferric chloride, Griess reagent, sodium nitroprusside, thiobarbituric acid, reduced glutathione, Folin ciocalteau reagent and other reagents used for this research were of analytical grade and were purchased from Sigma-Aldrich Co (St.Louis, USA)

Plant material: Seed of Phaseolus vulgaris was purchased from Maikatako market in Mangu local government of Plateau state in November 2018. It was identified and authenticated appropriately at Botany Department Bayero University Kano and was allocated a voucher specimen number of BUKHAN 613. Thereafter, the seeds were handpicked to remove stones and defected seeds. It was then milled to a fine powder and stored in a sealed container until it was required for extraction.
Preparation of the plant extract: Two hundred grams of the finely ground seed was dissolved in $200 \mathrm{ml}$ of various solvent (Hexane, dichloromethane, ethyl acetate, ethanol, and water) and were separately extracted by soaking in the solvent for 72 hours and occasional shaking using the hand. Filtration was carried out using Whatmann filter paper (No 1). Then the solvents were subjected to evaporation at reduced pressure using a rotary evaporator to obtain the extracts. However, the aqueous solvent was allowed to dry in a water bath at $50^{\circ} \mathrm{C}$. The extracts that were realized were weighed and stored in a refrigerator at $4{ }^{\circ} \mathrm{C}$ until they were needed for analysis.

Estimation of total phenol content: The method described by Escribano-Bailon and Santos-Buelga [21] was used for the determination of total phenol content. Briefly, Folin-Coicalteu method using gallic acid as a standard compound. Then $0.5 \mathrm{~mL}$ of the sample extract was mixed with $25 \mathrm{~mL}$ of deionized water, $2 \mathrm{~mL}$ of $7 \% \mathrm{Na}_{2} \mathrm{CO}_{3}, 0.5 \mathrm{~mL}$ of the Folinciocalteu reagent. At $735 \mathrm{~nm}$, against the blank sample, containing no sample mixture, the reaction mixtures absorbance was measured. Using a fivepoint calibration curve $(20-100 \mathrm{mg} / \mathrm{L})$, the total phenols were determined by a comparison of the values obtained with the calibration curve of gallic acid. All of measurements were conducted in the triplicate.

Determination of flavonoids: The flavonoid content was determined by Quvettier et al., [22]. Briefly, the samples were treated with $1 \mathrm{~mL}$ of $5 \% \mathrm{NaNO}_{2}$, then $1 \mathrm{~mL}$ of $10 \%$ of $\mathrm{Al}\left(\mathrm{NO}_{3}\right)_{2}$ including $10 \mathrm{~mL}$ of $4 \% \mathrm{NaOH}$ solution was added. The mixtures were allowed to stand at room temperature for 60 minutes. The absorbance values were taken from a spectrophotometer when it read $500 \mathrm{~nm}$. The content 
of flavonoids in extracts was reported as rutin equivalent in $\mathrm{mg} / \mathrm{g}$.

Anthocyanin content: Anthocyanin in all extracts was determined by methods previously described by [23]. Briefly, $0.5 \mathrm{~mL}$ of each sample was pipetted with a volumetric pipette into a $50 \mathrm{~mL}$ beaker; $2 \mathrm{~mL}$ of $0.025 \mathrm{M} \mathrm{KCl}$ was added, plus $2 \mathrm{~mL}$ of $0.4 \mathrm{M} \mathrm{CH}_{3} \mathrm{CO}_{2} \mathrm{Na}$. $3 \mathrm{H}_{2} \mathrm{O}$. The $\mathrm{PH}$ of the mixture was maintained at 4.5 at room temperature for 10 minutes with some occasional shaking. The diluted portion of each sample was turbid and cloudy. The contents were centrifuged at 200 r.p.m for 5 minutes. The centrifuged contents were read at $520 \mathrm{~nm}$ in a UV/visible spectrophotometer within 20-25 minutes of preparation. The standard solution was prepared at $(20-100 \mathrm{mg} / \mathrm{L})$. The calibration curve of the cyanidin- 3-glucoside was read along with the sample solutions.

\section{1-1-dipheny I-2 picrylhydrazyl free radical} scavenging activity (DPPH): The free radical scavenging ability of the extracts against DPPH $(1,1$ diphenyl-2 picrylhydrazyl) free radical was evaluated by what Tuba and Gulcin (2008) called a slighty modified method. Briefly, $0.3 \mathrm{mM}$ solution of DPPH was prepared in methanol and $500 \mu \mathrm{L}$ of the DPPH solution was added to $1 \mathrm{~mL}$ of the extracts at various concentrations $(15-240 \mu \mathrm{g} / \mathrm{mL})$. These solutions were mixed and incubated in the dark for 30 minutes at room temperature. The absorbance was read at 517 $\mathrm{nm}$ against blank samples lacking scavenger.

Ferric cyanide $\left(\mathrm{Fe}^{3+}\right)$ reducing antioxidant power (FRAP) assay: The total reducing power of the extracts was determined using the FRAP method of Oyaizu [25] with slight modifications. To perform this assay, $1 \mathrm{~mL}$ of each extract $(15-240 \mu \mathrm{g} / \mathrm{mL})$ was incubated with $1 \mathrm{~mL}$ of sodium phosphate buffer $(0.2$
$\mathrm{M}, \mathrm{pH}$ 6.6) and $1 \%$ potassium ferricyanide at $50^{\circ} \mathrm{C}$ for 30 minutes. Then, $1 \mathrm{~mL}$ of $10 \%$ trichloroacetic acid was used to acidify the reaction mixtures. After the acidification, $1 \mathrm{~mL}$ of the sample was mixed with $1 \mathrm{~mL}$ of distilled water and $200 \mu \mathrm{L}$ of $0.1 \% \mathrm{FeCl}_{3}$. The absorbance of the resulting solution was read at 700 $\mathrm{nm}$ in a spectrophotometer. The absorbance of the samples is proportional to the reduction capability of the extracts. The results were expressed as a percentage of the absorbance of the sample to the absorbance of Gallic acid. Ferric reducing antioxidant power $\%=$ Absorbance of sample/ Absorbance of Gallic acid X 100

\section{-2, 2'-azino-bis (3-ethylbenzothiazoline-6-sulphonic} acid) (ABTS) scavenging activity of $A B T S$ scavenging activity: The ABTS scavenging activity of the plant extract was determined using the method of Re et al., [26] Analysis was carried out in a triplicate.

Alpha amylase inhibitory activity: The $\alpha$-amylase inhibitory activity was measured according to Shai et al., [27] with slight modifications was used. A volume of $250 \mu \mathrm{L}$ of each extract or acarbose at different concentrations $(100-500 \mu \mathrm{g} / \mathrm{mL})$ was incubated with $500 \mu \mathrm{L}$ of porcine pancreatic amylase $(2 \mu / \mathrm{mL})$ in phosphate buffer (100 mM, pH 6.8) at $37^{\circ} \mathrm{C}$ for 20 minutes. Then, $250 \mu \mathrm{L}$ of $1 \%$ starch was dissolved in $100 \mathrm{mM}$ phosphate buffer ( $\mathrm{pH}$ 6.8) was further added to the reaction mixture and then incubated at $37^{\circ} \mathrm{C}$ for 1 hour. Then dinitro salicylate color reagent $(1 \mathrm{~mL})$ was added then left to boil for 10 minutes. The mixture resulted in an absorbance that read at $540 \mathrm{~nm}$, and the inhibitory activity was expressed without the inhibitors as a percentage of control.

Alpha glucosidase inhibitory activity: The $\alpha$ glucosidase inhibitory activity was determined by the method described by [10] with slight modifications. 
Briefly, $250 \mu \mathrm{L}$ of each extract or acarbose at different concentrations $(30-240 \mu \mathrm{g} / \mathrm{mL})$ was incubated with $500 \mu \mathrm{L}$ of $1.0 \mathrm{U} / \mathrm{mL} \alpha$-glucosidase solution in $100 \mathrm{mM}$ phosphate buffer (100mM, pH 6.8) at $37^{\circ} \mathrm{C}$ for 15 minutes. Then, $250 \mu \mathrm{L}$ of pNPG solution (5 mM) in phosphate buffer (100 mM, pH 6.8) was added and the reaction mixture was further incubated at $37^{\wedge}(0) C$ for 20 minutes. The absorbance of the released p-nitro phenol was measured at $405 \mathrm{~nm}$ and the inhibitory activity was expressed as a percentage of the control without the inhibition. All assays were carried out in a triplicate. The inhibitory activities of the extracts on the $\alpha$-glucosidase and $\alpha$-amylase were calculated by using the following formula:

Inhibitory activity $\%=(1-\mathrm{As} / \mathrm{Ac}) \times 100$

Where As: is the absorbance in the presence of the sample and Ac: is the absorbance of the control.

The concentration resulting in inhibition of $50 \%$ enzyme activity and scavenging activities $\left(\mathrm{IC}_{50}\right)$ were obtained by calculating from the plot of percentage inhibition against log (concentration of the samples)
Fourier Transform Infrared Analysis (FTIR): The FTIR analysis was carried out for the extracts of the using the software and FTIR spectroscope and scan range of $650-4000 \mathrm{~cm}^{-1}$ and a resolution of $8 \mathrm{~cm}^{-1}$.

Statistical Analysis: Data from this study were analyzed using statistical package software (SPSS for windows version 18) using Tukey's HSD multiple pos hoc test. The value of statistical significance was considered at $\mathrm{p}<0.05$.

\section{RESULTS}

The present study revealed that the various solvent extract showed a variable amount of polyphenol, flavonoid, and anthocyanin content. From the results, significantly $(p<0.05)$ higher amounts of total polyphenol and anthocyanin were detected in the aqueous extract compared to other solvent extracts. (Table 1) The ethanol extract however showed a much higher $(p<0.05)$ total flavonoids content in comparison to the other solvents.

Table 1: Total polyphenol, and anthocyanin and flavonoid contents of various solvent extracts of $P$.vulgaris seeds

\begin{tabular}{|l|l|l|l|}
\hline Samples & $\begin{array}{l}\text { Total polyphenols } \\
\text { content (mg/g GAE) }\end{array}$ & $\begin{array}{l}\text { Total flavonoids } \\
\text { content (mg/g QE) }\end{array}$ & $\begin{array}{l}\text { Anthocyanin content } \\
\text { (mg/g QE) }\end{array}$ \\
\hline Ethyl acetate & $4.91 \pm 0.02^{\mathrm{a}}$ & $0.49 \pm 0.01^{\mathrm{a}}$ & $28.83 \pm 0.34^{\mathrm{a}}$ \\
\hline Hexane & $3.07 \pm 0.01^{\mathrm{b}}$ & $0.37 \pm 0.01^{\mathrm{b}}$ & $36.49 \pm 0.32^{\mathrm{b}}$ \\
\hline Dichloromethane & $6.6 \pm 0.00^{\mathrm{c}}$ & $1.27 \pm 0.02^{\mathrm{c}}$ & $65.56 \pm 0.09^{\mathrm{c}}$ \\
\hline Aqueous & $13.9 \pm 0.01^{\mathrm{d}}$ & $1.14 \pm 0.03^{\mathrm{d}}$ & $76.34 \pm 1.12^{\mathrm{d}}$ \\
\hline Ethanol & $7.3 \pm 0.01^{\mathrm{e}}$ & $1.89 \pm 0.05^{\mathrm{e}}$ & $74.53 \pm 0.24^{\mathrm{e}}$ \\
\hline
\end{tabular}

Data are presented as mean \pm SD values of a triplicate determinations. Values within a column with different superscripts are significantly different from each other (Tukey's-HSD multiple range post hoc test, $p<0.05$ )

In vitro assay antioxidant assay: The in vitro antioxidant activities of the various solvent extract of seeds of P.vulgaris are displayed in figure 1-3 


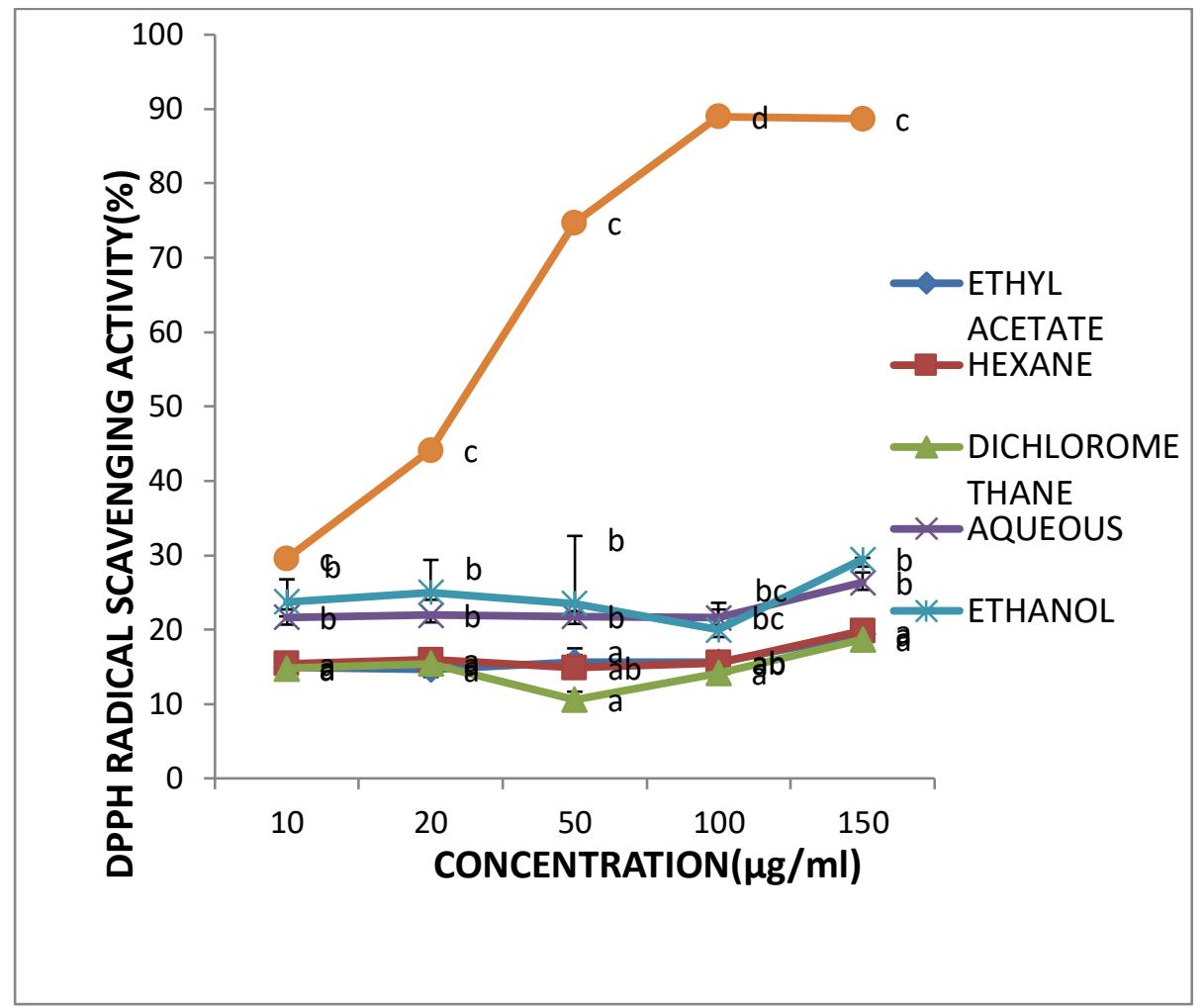

Figure 1: DPPH radical scavenging activities of seed extracts of P.vulgaris in different solvents. Values with different letters for each extract at a given concentration are significantly different from each other

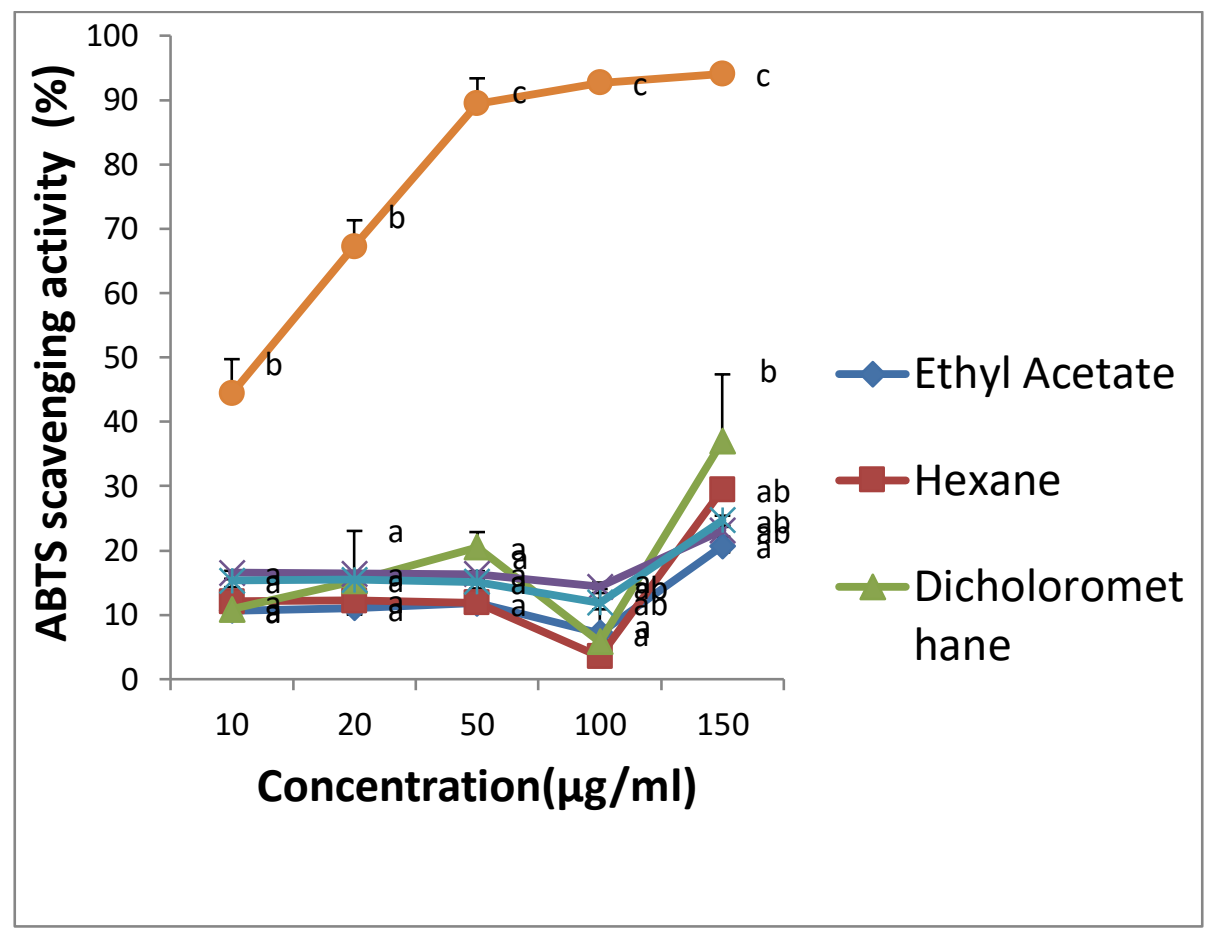

Figure 2: ABTS radical scavenging activities of seed extracts of $P$.vulgaris in different solvent. Values with different letters for each extract at a given concentration are significantly different from each other 




Figure 3: Ferric reducing antioxidant potential of seed extracts of P.vulgaris in different solvents. Data are presented as mean \pm SD of triplicate determinations.

The percentage inhibition of aqueous and ethanol extract was significantly higher $(p<0.05)$ than those of hexane, dichloromethane, and ethyl acetate extract for DPPH radical scavenging activity. (Figure1.) However, percentage inhibition of the standard was significantly higher than solvent extracts that varied in concentrations $(10-150 \mu \mathrm{g} / \mathrm{ml})$ used. The result of ABTS of extracts from P. vulgaris seeds showed that at $10-100 \mu \mathrm{g} / \mathrm{ml}$ there was no significant difference amongst the extracts. However, at the highest concentration $(150 \mu \mathrm{g} / \mathrm{ml})$, extracts of dichloromethane had significantly higher percentage inhibition than ethyl acetate. Dichloromethane, hexane, ethanol, and aqueous extracts showed no significant difference between each other. (Figure 2). The standard had a significantly higher percentage activity $(p<0.05)$ than all extract at all concentrations. Figure 3 shows the percentage inhibition of Ferric reducing power. Results revealed a weak activity of all the solvent extracts which was observed to decrease as concentration increases. There was no significant difference amongst all the extracts however the ascorbic acid significantly had a higher percentage inhibition activity than all the extracts. Table 2 shows the calculated $\mathrm{IC}_{50}$ of different solvent extract of Phaseolus vulgaris seed in antioxidative model used. The calculated $\mathrm{IC}_{50}$ indicated that the extracts of the various solvents did not vary significantly from each other but were significantly $(p<0.05)$ different from ascorbic acid. (Table 2). The result of DPPH showed the $I C_{50}$ value of ascorbic acid $(1.35 \pm 0.006 \mathrm{mgml})$ to be significantly $(p<0.05)$ lower than all the solvent extracts. Ethanol extract had the lowest $I_{50}$ value $(12.54 \pm 2.30 \mathrm{mg} / \mathrm{ml})$ among the solvent extracts though not significantly different from the other extracts. The $I C_{50}$ values recorded were $12.59 \pm 2.33$, $12.92 \pm 2.30,20.45 \pm 6.49$ and $26.12 \pm 4.94 \mathrm{mg} / \mathrm{ml}$ for aqueous, ethyl acetate, hexane and dichloromethane extract respectively. (Table 2 ) For $A B T S$, the $\mathrm{IC}_{50}$ value of ascorbic acid $(0.96 \pm 0.111 \mathrm{mgml})$ was also significantly higher $(p<0.05)$ than all the tested solvent extracts, with the exception of dichloromethane $(5.69 \pm 2.886 \mathrm{mgml})$ which did not vary significantly from ascorbic acid. There was no 
significant difference between the $I C_{50}$ values of hexane $(6.92 \pm 0.114 \mathrm{mgml})$ and dichloromethane. Ethanol (10.10 $\pm 1.110 \mathrm{mgml})$, ethyl acetate $(10.76 \pm 2.998 \mathrm{mgml})$ and aqueous $13.24 \pm 3.6 \mathrm{mg} / \mathrm{ml}$ had $I_{50}$ values that did not significantly differ from each other. For FRAP, IC $C_{50}$ values indicated that the solvents' extracts significantly differed from each other. Ascorbic acid possessed $I_{50}$ value $(1.59 \pm 0.003$ mgml) which was significantly lower than all solvent extracts. Ethanol extract had the least $\mathrm{IC}_{50}$ value of $80.78 \pm 0.6 \mathrm{mg} / \mathrm{ml}$ when compared with other solvent extracts.

Table 2:IC $\mathrm{C}_{50}$ of different solvent extract of Phaseolus vulgaris seed in antioxidative model used.

\begin{tabular}{|l|l|l|l|}
\hline SAMPLES & DPPH scavenging activity & ABTS & Ferric reducing antioxidant \\
potential
\end{tabular}

Data are presented as mean \pm SD values of triplicate determinations. Values within a column with different superscripts are significantly different from each other (Tukey's-HSD multiple range post hoc test, $p<0.05$ )

Table 3: Values of IC50 of different solvent extracts of P.vulgaris seeds in the anti-oxidative and anti-diabetic models.

\begin{tabular}{|lll|}
\hline SAMPLES & \multicolumn{1}{l}{$\mathrm{C}_{50}(\mu \mathrm{g} / \mathrm{ml})$} & \\
\hline Ethyl acetate & $\alpha$ amylase inhibition & glucosidase inhibition \\
\hline Hexane & $4.19 \pm 1.17^{\mathrm{b}}$ & $3.07 \pm 0.61^{\mathrm{abc}}$ \\
\hline Dichloromethane & $2.87 \pm 0.11^{\mathrm{ab}}$ & $3.44 \pm 0.46^{\mathrm{c}}$ \\
\hline Aqueous & $2.81 \pm 0.12^{\mathrm{ab}}$ & $2.22 \pm 0.11^{\mathrm{bc}}$ \\
\hline Ethanol & $3.15 \pm 0.18^{\mathrm{ab}}$ & $2.82 \pm 0.14^{\mathrm{ab}}$ \\
\hline Acarbose & $3.72 \pm 0.40^{\mathrm{ab}}$ & $2.60 \pm 0.61^{\mathrm{a}}$ \\
\hline
\end{tabular}

Data are presented as the mean \pm SD the values of a triplicate determinations. Values within a column with different superscripts are significantly different from each other (Tukey's-HSD multiple range post hoc test, $p<0.05$ )

The FTIR analysis (Figure 4) of ethanol extract showed characteristic's absorption bands at $3378 \mathrm{~cm}^{-1}$ and
$1052 \mathrm{~cm}^{-1}$ (C-O) for hydroxyl (OH) group. The peaks obtained at $1745 \mathrm{~cm}^{-1}$ represents a carbonyl group 
( $C=0$ ) and $1640 \mathrm{~cm}^{-1}$ for $\mathrm{C}=\mathrm{C}$ group. $\mathrm{C}=\mathrm{O}$ stretching at $1745 \mathrm{~cm}^{-1}$ could be aldehyde or ketone functional

group. The $\mathrm{C}=\mathrm{C}$ stretching is an aromatic bending, $1052 \mathrm{~cm}^{-1}$ is for aromatic and alkane bending.

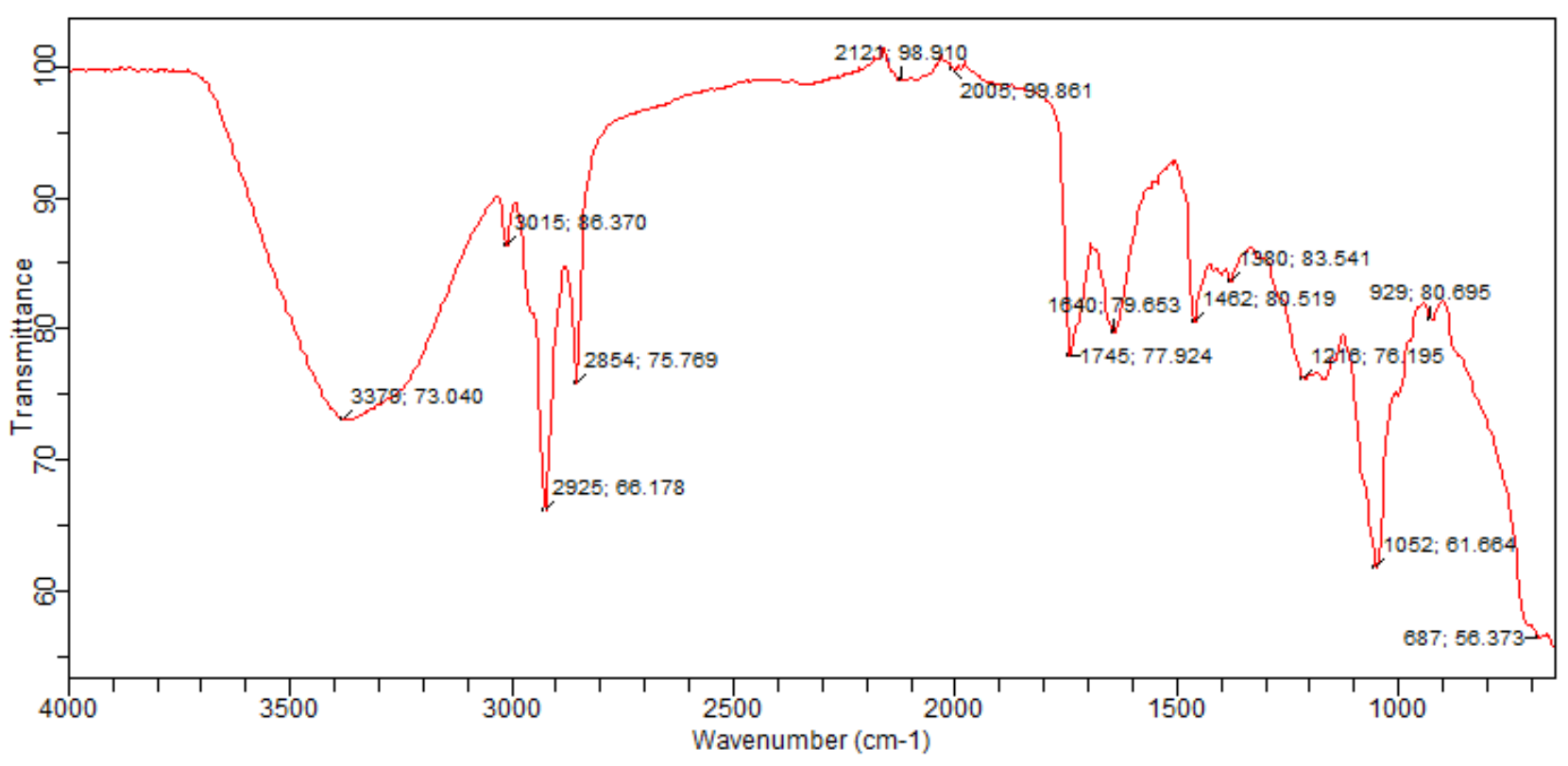

Figure 4: Fourier Transformation infra red (FTIR) spectra of Ethanol extract of P.vulgaris seeds

Invitro antidiabetic activity: Antidiabetic activities were determined by calculating the percentage inhibition of the extracts on two key enzymes of carbohydrate metabolism. The data of $\alpha$ Glucosidase $\alpha$ amylase and inhibition of the different solvent extracts are shown in Table 3. From the results, all the extracts showed $\alpha$ amylase and $\alpha$ glucosidase inhibitory action in a dose dependent manner. The percentage inhibition of the standard antidiabetic drug was significantly $(P<0.05)$ higher than all other extracts at concentrations of 400 and $500 \mu \mathrm{g} / \mathrm{ml}$. However, at lower concentrations (100-300 $\mu \mathrm{g} / \mathrm{ml})$ ethyl acetate, hexane, aqueous and dichloromethane extracts were not significantly different from the standard. Ethanol extract had the least percentage inhibition activity against $\alpha$ amylase. The $\alpha$ Glucosidase percentage inhibitory activity, results show that both aqueous and ethanol extracts were significantly higher than other extracts but did not vary significantly from the standard drug, acarbose at all the tested concentrations. For $\alpha$ amylase inhibition ethyl acetate had the highest $(4.19 \pm 1.17) I_{50}$ value. (Table 3$)$ and it was significantly $(p<0.05)$ different from the other solvent extracts and Acarbose. All other solvent extracts were comparable with acarbose $(2.49 \pm 0.53 \mathrm{mg} / \mathrm{ml})$. Ethanol extracts displayed significantly $\mathrm{p}(<0.05)$ lower $\mathrm{IC}_{50}(2.60 \pm 0.61)$ when compared with other solvent extracts. $I_{50}$ values of ethyl acetate and aqueous (3.07 \pm 0.61 and $2.8 \pm 0.61)$ including that of ethanol extract did not differ significantly from that of the Acarbose.

\section{DISCUSSION}

Research has shown that phytochemicals such as carotenoids, minerals, polyphenols, and vitamins found in multiple forms of food can exhibit antioxidant properties [28-29]. Previous work has shown that different extracts of Phaseolus vulgaris seed are rich in both polyphenols, flavonoids and in anthocyanin. [30-32]. Maria et al. reported that the black variety of Phaseolus vulgaris [32]. Anthocyanin content was higher in our samples as compared to 
those reported by other researchers, wide differences could arise due to different cultivation techniques, extraction methods, environmental factors, storage conditions and quantification procedures in Phaseolus vulgaris species [33-34]. Other researchers have reported that large amount of anthocyanin, polyphenol, and flavonoids. Our present research further corroborates the fact that ethanol being a polar solvent is the superior choice for extraction of the polyphenols and flavonoids. The high amount of anthocyanin found in this legume further suggests that it could serve as a useful source of not only anthocyanin but also polyphenols and flavonoids.

To assess the antioxidant activity of the extracts, various in vitro antioxidant models were utilized. All solvents' extracts displayed antioxidant activity though it was observed the extracts had a significantly lower antioxidant activity when compared with the standard this could be because of the fact that the seed coat of the Phaseolus vulgaris has been reported to be the reason for high antioxidant activity, however the whole bean seed was used in the present study. Antioxidants are compounds that are able to either inhibit or delay the oxidation processes 35]. This occurs under when it is under the influence of phenolic compounds, as they are linked to their ability to scavenge free radicals [8, 36]. DPPH is a popular method for assessing the antioxidant activity of extracts, fractions, or pure compounds. It is often employed as a substrate because of its ability to accept electrons or hydrogen ion from antioxidants thus becomes a stable molecule that can then be used to assess the in vitro free radical scavenging antioxidative ability of compounds [37]. In this model that was used, the extracts showed free radical scavenging activities though the calculated $\mathrm{IC}_{50}$ were higher than that of the ascorbic acid, the ethanol extract however had the least $I_{50}$ when compared with the other solvent extract.

The ABTS radical measures the antioxidant activities of plant extracts. The radical absorbs at 743 $\mathrm{nm}$ to give a bluish green color, an electron is lost by the nitrogen atom of ABTS, which causes formation. The various solvent extract and standard scavenged the ABTS radical in a concentration dependent manner. The dichloromethane and hexane extract had the higher radical scavenging activity in comparison to the other solvent extract. The differences that were observed in the activity of the plant extracts may be because of the different solvent, the process by which free radical scavenging activity occurs, and their solubility in various testing models [38]. The ability of plant extracts to reduce compounds can be measured by the FRAP in which Fe ${ }^{3+}$ is converted to $\mathrm{Fe}^{\wedge}(2+$.) All solvents extract showed antioxidant activity even though had a lower activity when compared to ascorbic acid. The observed decrease in antioxidant FRAP activity with increase in concentration, underscores the importance of employing different antioxidant assays in research. The result is an indication that the legume extract may possess ability to lessen oxidative damage.

The hallmark of diabetes mellitus is uncontrolled blood glucose level which leads to hyperglycemia; therefore, control of postprandial hyperglycemia is very critical in the management and in preventing complications at an early stage of the disease [39]. A strategy that can be used in achieving this is by the delay of glucose absorption by inhibiting $\alpha$ amylase and $\alpha$-glucosidase, which are key enzymes in carbohydrate metabolism. Disaccharides and oligosaccharides are released by the action of $\alpha$ amylase, which catalyzes the endo hydrolysis of $\alpha$ I, 4glycosidic linkage, $\alpha$-glucosidase further hydrolyses the disaccharides to glucose at the small intestinal 
brush border [40-41]. Research has shown that consumption of varieties of legumes including beans may be crucial in managing diabetes and in the control of blood glucose. Bean consumption has been shown to regulate blood glucose and insulin levels [42-43] Tan et al., had previously reported $\alpha$ amylase and glucosidase inhibitory of the fraction of black turtle bean extract [44]. They reported $I_{50}$ values of $0.25 \mathrm{mg} / \mathrm{ml}$ and $0.67 \mathrm{mg} / \mathrm{ml}$ against $\alpha$ glucosidase and amylase respectively. Ombra et al reported that extracts of red and speckled varieties of Phaseolus vulgaris showed inhibitory enzyme activities with IC $\mathrm{C}_{50}$ values ranging from $39.3 \pm 4.4$ to $79.13 \pm 6.9 \mu \mathrm{g} / \mathrm{ml}$ for $\alpha$ amylase and from $51 \pm 7.7$ to $122.1 \pm 5.2 \mu \mathrm{g} / \mathrm{ml}$ for $\alpha$ glucosidase [32]. However, our results recorded lower $\mathrm{IC}_{50}$ values of $3.72 \pm 0.40 \mathrm{mg} / \mathrm{ml}$ for $\alpha$ amylase and $2.60 \pm 0.61 \mathrm{mg} / \mathrm{ml}$ for $\alpha$ glucosidase for ethanol extract, which had the lowest $I C_{50}$ value for $\alpha$ glucosidase than the other solvent extracts, for the alpha amylase the ethanol extract had the least inhibitory activity after ethyl acetate. This is however desirable as it has been shown that plants that exhibit mild inhibitory action on alpha amylase but potent activity on $\alpha$-glucosidase are good candidates for antidiabetic drugs as they are able to reduce the side effects, such as flatulence, indigestion, and diarrhea accompanied with the use of synthetic $\alpha$ glucosidase inhibitor drugs [45-46]. Our findings also support earlier reports that plant extracts show higher inhibitory activities on $\alpha$-glucosidase than $\alpha$-amylase [47]. Hence, it can be suggested that the presence of metabolites that serve as bioactive inhibitors are more in the ethanol extract than the other solvent extracts.

Various plants constituents like terpenes, alkanes, phenols, amino acids are responsible for the medicinal properties of plants; hence, the biological activities can be understood by the analysis of these chemical constituents [48]. The presence of a functional group in a phytochemical can be identified by the Fourier- Transform Infrared spectrophotometer. It is an important technique used to establish the identity of the chemical bond and functional groups found in plants. FT-IR analysis of the ethanol extract showed the presence of polyphenol and flavonoids to $\mathrm{OH}$ stretching, terpenes due to $\mathrm{C}-\mathrm{H}$ group. Secondary metabolites that may be present in the ethanol extracts are flavonoids, anthocyanins, coumarins, and phenolics. The presence of functional groups like alcohol, aldehyde and ketone functional group may be responsible for the antioxidative and antidiabetic properties that the extract may display. Various types of legumes are consumed globally; recently Phaseolus vulgaris species have received growing attention due to its possession of abundant nutrients and healthy giving additives like dietary antioxidants, polyphenols, and fiber [49]. In previous studies researchers have found there to be a positive correlation between ones consumption of legumes and their risk of chronic disease decreasing [50-51]. Several phytochemical studies have been reported on varieties of Phaseolus vulgaris, including the black bean variety. Aqueous extract of black bean has been shown to be rich in phenolic, tryptophan, and omega3 fatty acids Some known polyphenols, for instance, gallic acid, chlorogenic acid, epicatechin, myricetin, formononetin caffeic acid and kaempferol have also been discovered, Nnabuenyi and Awuzie reported the presence of Vitamins B1, B2 and C in both fresh and dry seeds of the black turtle bean, with vitamin $A$ found to be present in only the fresh seeds [20].

A study on the Phaseolus vulgaris grown in Nigeria revealed that it has both nutritional and medicinal value due to the presence of secondary metabolites, which have therapeutic properties [52]. Hence, our present study underscores the 
importance of further develop this legume by finding more bioactive compounds and investigating their health benefit or their biologically active metabolite, which can be targeted towards preventing and managing diabetes mellitus.

\section{CONCLUSION:}

In conclusion, different solvent extracts from the seed of Phaseolus vulgaris have demonstrated low antioxidative but very promising anti -diabetic activities in vitro. The ethanol extract however displayed higher activity than other solvent extracts, FT-IR results of ethanol extracts revealed the presence of flavonoids anthocyanins and phenolics. This study may suggest that seeds of Phaseolusulgaris signify a functional food and nutraceutical in the management of Type 2 diabetes. More studies are needed to isolate and identify the specific compounds with the $\alpha$ amylase and $\alpha$ glucosidase inhibitory properties.

Abbreviations: FTIR: Fourier Transformation infrared, DNSA: 3, 5-dinitrosalicylic acid, pNPG: pnitrophenyl- $\alpha-D$-glucopyranoside, DPPH: 1,1diphenyl-2-picrylhydrazyl radical, UV: Ultraviolet

\section{REFERENCES}

1. Babu NP, Pandikumar P, Ignacimuthu S: Anti-inflammatory activity of Albizia lebbeck Benth., an ethnomedicinal plant, in acute and chronic animal models of inflammation. Journal of Ethnopharmacology 2009, 125(2):356360. https://doi.org/10.1016/j.jep.2009.02.041

2. Sokmen A, Jones, BM, Erturk, M: The in vitro antibacterial activity of Turkish medicinal plants. Journal of Ethnopharmacology 1999, 67(1):79-86. https://doi.org/10.5897/AJFS2015.1402.

3. Olaiya CO, Soetan KO, Esan AM: The role of nutraceuticals, functional foods and value added food products in the prevention and treatment of chronic diseases. Afr. J. Food 2016, 10(10):185-193.

https://doi.org/10.5897/AJFS2015.1402 spectrophotometer, FRAP: Ferric cyanide $\left(\mathrm{Fe}^{3+}\right)$ reducing antioxidant power, ABTS: -2, 2'-azino-bis (3ethylbenzothiazoline-6-sulphonic acid), IC: Inhibition concentration

Authors' contribution: Study concept and design: Muntari Bala, Balkisu Abdulrahman Analysis and interpretation of data: Balkisu Abdulrahman, Oluwasesan Bello; Drafting of the manuscript: Balkisu Abdulrahman, Revision and editing of the manuscript Muntari Bala; Statistical analysis: Balkisu Abdulrahman, Oluwasesan Bello

Conflicts of Interest: No conflicts of interest among the authors.

Acknowledgement: This work was supported by Tertiary Education Trust Fund (TETfund) Nigeria through Federal University Dutsin- Ma, Katsina state, Nigeria under the Academic Staff Training and Development 2018-2019 (merged intervention). TETF/DASTD/UNIV/KATSINA STATE/TSAS/2019/VOL.1
4. International Diabetes Federation (IDF): Diabetes Atlas. 9th ed. [http://www.idf.org/diabetesatlas/update-2019] Retrieved 27 September 2021

5. World Health Organization (WHO). [ https://www.who.int/news-room/factsheets/detail/diabetes;2020] Retrieved 27 September 2021

6. Oputa RN, Chineye S: Diabetes in Nigeria: A translational medicine approach. Afr. J Diab. Med. 2015 23(1):7-10

7. Brownlee M: Biochemistry and Molecular cell biology of diabetic complications. Nature ,2001 414(6865):813-820.

8. Maria-Luisa LVM, Cristina FM: Oxidative Stress in Diabetes Mellitus and the Role of Vitamins with Antioxidant Actions. In book: Oxidative Stress and Chronic Degenerative Diseases. A Role of Antioxidants 2013 http://dx.doi.org/10.5772/51788 
9. Halliwell B. The antioxidant paradox. Lancet. 2000 1:355(9210):1179-80. https://doi.org:10.1016/S01406736(00)02075-4

10. Ademiluyi AO, Oboh G: Soybean phenolic-rich extracts inhibit key-enzymes linked to type 2 diabetes ( $\alpha$-amylase and $\alpha$-glucosidase) and hypertension (angiotensin । converting enzyme) in vitro Exp. Tox. Pathol. 2013, (65):305309. https://doi.org/10.1016/j.etp.2011.09.005

11. Odetola AA, Akinloye O, Egunjobi C, Adekunle, WA Ayoola AO: Possible antidiabetic and antihyperlipidaemic effect of fermented Parkia biglobosa (JACQ) extract in alloxaninduced diabetic rats. Clin. Exp. Pharmacol. Physiol. 2006.33:808-812. $\quad$ https://doi.org/10.1111/j.14401681.2006.04444.x

12. Oboh G, Akinyemi AJ, Ademiluyi AO, Adefegha SA: Inhibitory effects of aqueous extracts of two varieties of ginger on some key enzymes linked to type-2 diabetes in vitro. Journal of Food Nutrition Research. 2010, 49: 14-20.

13. Gepts P, Debouck, DG: Origin, domestication, and evolution of the common bean (Phaseolus vulgaris L.). In: van Schoonhoven, A., Voysest, O. (eds.). Common beans: research for crop improvement. Commonwealth Agricultural Bureaux International, Wallingford, United Kingdom.1999, 7-53.

14. Mishra SB, Rao CV, Ojha, SK, Vijayakumar, M, Verma: An analytical review of plants for anti- diabetic activity with their phytoconstituent and mechanism of action: a review, Int. J. Pharm. Sci. Res. 2010, 1(1):29-44.

15. Kotue $T C$, Jayamurthy $P$, Nisha $P$, Pieme AC, Kansci, $G$, Fokou E, Ashok P: Proximate Analysis and Minerals of Black Bean Seeds (Phaseolus vulgaris L.) Used to Manage Sickle Cell Disease in West Region of Cameroon. AFSJ 1(4):182018. https://doi.org/10.9734/AFSJ/2018/40521.

16. Weiss RF, Fintelmann V: Herbal Medicine. (2 ${ }^{\text {nd }}$ ed). Pub. Thieme Stuttgart, New York, USA, 2000,1:28-129

17. Karen P: Evaluation of the Antioxidant and Antiinflammatory Activity of Extracts and Flavonol Glycosides Isolated from the Seed Coats of Colored Beans Phaseolus vulgaris L. Master thesis University of Manitoba Winnipeg, Manitoba. Department of Food Science; 2011 https://mspace.lib.umanitoba.ca/bitstream/1993/4794/1/ pitura karen.pdf

18. Dong M, Xiangjiu H, Rui HL: Phytochemicals of Black Bean Seed Coats: Isolation, Structure Elucidation, and Their Antiproliferative and Antioxidative Activities. J. Agric. Food Chem. 2007(55) 6044-605. https://doi.org/10.1021/jf070706d

19. Chavez-Santoscoy Rocio A, Janet A. Gutierrez-Uribe, Omar Granados, Ivan Torre-Villalvazo, Sergio O. Serna-Saldiva, Nimbe Torres, Berenice Palacios-Gonza'lez and Armando R. Tovar: Flavonoids and saponins extracted from black bean (Phaseolus vulgaris L.) seed coats modulate lipid metabolism and biliary cholesterol secretion in C57BL/6 mice. $\quad \mathrm{Br} \quad \mathrm{J}$ Nutr 2014112:886-899 http://dx.doi.org/10.1017/S0007114514001536

20. Abdulrahman BO, Bala M, Bello OM: Bioactive Compounds of Black Bean (Phaseolus vulgaris L.). In Bioactive Compounds in Underutilized Vegetables and Legumes, Reference Series in Phytochemistry. Edited by Murthy, KY Paek. Springer, Cham. 2020:623-641 https://doi.org/10.1007/978-3-030-44578-2 38-1

21. Escribano-Bailon MT, Santos-Buelga C, Polyphenols Extraction from Foods. In: Methods in

Polyphenol Analysis. Edited by Santos-Buelga C, Williamson G). Royal Society of

Chemistry, Cambridge, United Kingdom 2003:1-16.

22. Quvettier DC, Gressier B, Vasseur J, Dine T, Brunet E, Luyckx MC: Phenolic compounds and anti-oxidant activities of buck wheat. (Fagopyrum esculentum Moench) hulls and $\begin{array}{llll}\text { flour. J } & \text { (72):35-42. }\end{array}$ https://doi.org/10.1016/SO378-8

23. Lee J, Durst RW, Wrolstad RE: Determination of total monomeric anthocyanin pigment content of fruit juices, beverages, natural colorants, and wines by the $\mathrm{pH}$ differential method: collaborative study. J AOAC Int. 2005 88(5):1269-78.

24. Tuba AK, Gulcin I: Antioxidant and radical scavenging properties of curcumin. Chemico- Biol. Inter 2008, 174:2737. https://doi.org/10.1016/j.cbi.2008.05.003

25. Oyaizu M: Studies on potent of browning reactions: Anti oxidative activities of products of browning reaction prepared from glucosamine. Japan J. Nutr 1986, 44: 307-315 https://doi.org/10.5264/eiyogakuzashi.44.307

26. Re R, Pellegrini N, Proteggente A, Pannala A, Yang M, Rice-Evans C. Antioxidant activity applying an improved ABTS radical cation decolorization assay. Free Radic Biol Med. 1999 26(9-10):1231-7. http://doi.org/10.1016/S0891-5849

27. Shai $\sqcup$, Masoko P, Mokgotho MP, Magano SR, Mogale AM, Boaduo N, Eloff JN: Yeast alpha glucosidase inhibitory and antioxidant activities of six medicinal plants collected in 
Phalaborwa, South Afr. J. Bot 2010 76(3) 465-470. https://doi.org/10.1016/j.sajb.2010.03.002

28. Adefegha SA and Oboh G: Phytochemistry and mode of action of some tropical species in the management of type2 diabetes and hypertension: African Journal of Pharmacy and Pharmacology 2013 7(7)332-346. https://doi.org/10.5897/AJPPX12.014

29. Scalbert A, Manach C, Morand C, Remesy C: Dietary polyphenols and the prevention of diseases. Crit. Rev. Food Sci. Nutr. 2005 (45):287-306. https://doi.org/10.1080/1040869059096

30. Aquino-Bolaños EN, García-Díaz YD, Chavez-Servia JL, Carrillo-Rodríguez JC, Vera-Guzmán AM, Heredia-García E. Anthocyanin, polyphenol, and flavonoid contents and antioxidant activity in Mexican common bean (Phaseolus vulgaris L.) landraces. Emirates Journal of Food and Agriculture. 2016 1: 581-588. https://doi.org/10.9755/ejfa.2016-02-147

31. Kan L, Nie S, Hu J, Liu Z, Xie M: Antioxidant activities and anthocyanins composition of seed coats from twenty-six kidney bean cultivar. Journal of Functional Foods 2016 (26):622-631. http://dx.doi.org/10.1016\%2Fj.jff.2016.08.030

32. Ombra MN, d'Acierno A, Nazzaro F, Riccardi R, Spigno P, Zaccardelli M, Pane C, Maione M, Fratianni F. Phenolic Composition and Antioxidant and Antiproliferative Activities of the Extracts of Twelve Common Bean (Phaseolus vulgaris L.) Endemic Ecotypes of Southern Italy before and after Cooking. Oxid Med Cell Longev 2016(2016):1398298. https://doi.org/10.1155/2016/1398298

33. Renuka , Thakur DR: Quantitative analysis of Total flavonoids and phenolics contents of ten genotypes of Phaseolus vulgaris Linnaeus. Asian Journal of Biological Sciences 2014 7(1):24-29 https://dx.doi.org/10.3923/ajbs.2014.24.29

34. Boateng J. Vergese M, Walker LT Ogutu S: Effect of processing on the antioxidants content in selected dry beans Phaselous spp. LWT Food science and Technology 2008,41 (9) 1541-1547. https://doi.org/10.1016/j.lwt.2007.11.025

35. Pisoschi AM, Negulescu GP: Methods for Total Antioxidant Activity Determination: A Review. Biochem \& Anal Biochem 2011, (1):106. https//:doi.org/10.4172/2161-1009.1000106

36. Rezaieh M, Farhoosh $R$, Iranshahi M, Sharif A, Golmohamadzadeh S: Ultrasonic-assisted extraction of antioxidative compounds from Bene (Pistacia atlantica subsp.mutica) hull using various solvents of different physicochemical properties. Food Chem; 2015, 173:577874. https://doi.org/10.1016/j.foodchem.2014.10.081

37. Wu N, Zu Y, Fu Y, Kong Y, Zhao J, Li X, Li J, Wink M, Efferth T: Antioxidant activities and xanthine oxidase inhibitory effects of extracts and main polyphenolic compounds obtained from Geranium sibiricum L.J.Agric.FoodChem 20105,8: 4737-4743. https://doi.org/10.1021/jf904593n

38. Oyedemi S, Bradley G, Afolayan A : In vitro and in vivo antioxidant activities of aqueous stem bark extract of strychnos henningsii Gilg. Afr.J. Pharmcol. 2010 4: 070-078 https://doi.org/10.5897/AJPP.9000176

39. Ali H, Houghton, PJ, Soumyanath A: Alpha amylase inhibitory activity of some Malaysian plants used to treat diabetes; with particular reference to Phyllanthus amarus. Journal of Ethnopharmacology.2006, (107): 449-455. https://doi.org/10.1016/j.jep.2006.04.004

40. Hua-Qiang D, Mei L, Feng, Z., Fu-Lai L Jian-Bo H: Inhibitory potential of trilobatinfrom Lithocarpus polystachyus Rehd against $\alpha$-glucosidase and $\alpha$-amylase linked to type 2 diabetes. Food Chemistry. 2012, (130):261-26. https://doi.org/10.1016/j.foodchem.2011.07.030

41. Hanhineva K, Törrönen R, Bondia-Pons I, Pekkinen J, Kolehmainen, $\mathrm{M}$, Mykkänen, $\mathrm{H}$ Poutanen $\mathrm{H}$ : Impact of dietary polyphenols on carbohydrate metabolism. International Journal of Molecular Sciences. 2010, 11:13651402. https://doi.org/10.3390/ijms1104136

42. Venn BJ, Mann JI: Cereal grains, legumes and diabetes. Eur J Clin Nutr 2004, (58):1443-1461. https://www.nature.com/articles/1601995/metrics

43. Leathwood P, Pollet P: Effects of slow release carbohydrates in the form of bean flakes on the evolution of hunger and satiety in man. Appetite.1988, 10(1):1-1 https://doi.org/10.1016/s0195-6663(88)80028-x1

44. Tan Y, Chang SKC, Zhang Y: Comparison of $\alpha$-amylase, $\alpha$ glucosidase and lipase inhibitoryactivity of the phenolic substances in two black legumes of different genera. Food Chem 2017,1(214):259-268

https://doi.org/10.1016/j.foodchem.2016.06.100

45. Oboh G, Akinyemi AJ, Ademiluyi AO and Bello FO : Inhibition of $\alpha$-amylase and $\alpha$-glucosidase activities by ethanolic extract of Amaranthus cruentus leaf as affected by blanching. African Journal of Pharmacy and Pharmacology 2013, 7(17): 1026- 1032. https://doi.org/10.5897/AJPP12.595 
46. Ranilla LG, Kwon YI, Apostolidis E, Shetty K: Phenolic compounds, antioxidant activity and in vitro inhibitory potential against key enzymes relevant for hyperglycemia and hypertension of commonly used medicinal plants, herbs and spices in Latin America. Bioresource Technology 2010, 101 (12): 4676-4689.

https://doi.org/10.1016/j.biortech.2010.01.093

47. Adefegha, S.A. Oboh, G: Antioxidant and Inhibitory Properties of Clerodendrum volubile Leaf Extracts on Key Enzymes Relevant to Non-insulin dependent diabetes mellitus and Hypertension, Journal of Taibah University for Science 2016, 10(4):521-533

http://dx.doi.org/10.1016/j.jtusci.2015.10.008

48. Kalaichelvi K, Dhivya SM: Screening of Phytoconstituents. UV-VIS Spectrum and FTIR analysis of Micrococca mercurialis (L.) Bent. International Journal of Herbal Medicine. 2017, 5(6): 40-44
49. Dueñas $M$, Martínez-Villaluenga $C$, Limón, RI, Peñas $E$, Frias $\mathrm{J}$ : Effect of germination and elicitation on phenolic composition and bioactivity of kidney beans Food Research International, 2015 70:53-63.

https://doi.org/10.1016/j.foodres.2015.01.018

50. Nouri F, Sarrafzadegan N, Mohammad FN, Sadeghi M., Mansourian, $M$ : Intake of legumes and the risk of cardiovascular disease: Frailty modeling of a prospective cohort study in the Iranian middle-aged and older population European Journal of Clinical Nutrition 2016, 70217-221.

https://doi.org/10.1016/s0195-6663(88)80028-x

51. Messina V. Nutritional and health benefits of dried beans: Am J Clin Nutr. 2014,100 (1):437S-42S. https://doi.org/10.3945/ajcn.113.071472

52. Ikezu UJ, Udeozo IP, Egbe DE: Phytochemical and Proximate Analysis of Black Turtle Beans (Phaseolus vulgaris) African J. Basic and Appl. Sci .2015 7(2): 88-90. https://doi.org/10.5829/idosi.ajbas.2015.7.2.1142 